\title{
Pseudonocardia eucalypti sp. nov., an endophytic actinobacterium with a unique knobby spore surface, isolated from roots of a native Australian eucalyptus tree
}

\author{
Onuma Kaewkla and Christopher M. M. Franco
}

Correspondence

Christopher M. M. Franco

chris.franco@flinders.edu.au

\author{
Department of Medical Biotechnology, Flinders University, Bedford Park, Australia
}

The genus Pseudonocardia was originally proposed by Henssen (1957). Members of the genus possess type IV cell walls that are of the non-mycolate type and contain mesodiaminopimelic acid, arabinose and galactose. The major menaquinone is MK-8 $\left(\mathrm{H}_{4}\right)$ and phospholipids are either type PII or PIII. Members of the genus have DNA G+C contents ranging from 68 to $79 \mathrm{~mol} \%$ and, in phylogenetic trees, form a consistent cluster within the evolutionary radiation of the family Pseudonocardiaceae (McVeigh et al., 1994; Warwick et al., 1994; Reichert et al., 1998; Lee et al., 2000). At the time of the writing, the genus contained more than 30 species with validly published names (http://www. bacterio.cict.fr/p/pseudonocardia.html). Most strains of these species were isolated from soil but some strains were isolated from a variety of sources such as coastal sediment (Liu et al., 2006), tree bark compost (Reichert et al., 1998), a gold mine (Lee et al., 2001) and from 1,4-dioxanecontaminated industrial sludge (Mahendra \& AlvarezCohen, 2005). Recent reports have described five novel

Abbreviations: FAME, fatty acid methyl esters; SEM, scanning electron microscopy.

The GenBank/EMBL/DDBJ accession number for the 16S rRNA gene sequence of strain EUM $374^{\top}$ is FJ805426.

Three supplementary figures are available with the online version of this paper. species of endophytic origin in this genus: Pseudonocardia alni, isolated from root nodules of an alder tree (Evtushenko et al., 1989; Warwick et al., 1994); Pseudonocardia oroxyli, from a surface-sterilized root of Oroxylum indicum $(\mathrm{Gu}$ et al., 2006); Pseudonocardia endophytica, from the inner tissue of Lobelia clavata (Chen et al., 2009); Pseudonocardia acaciae, from roots of Acacia auriculiformis (Duangmal et al., 2009) and Pseudonocardia adelaidensis, also isolated from the stem of a eucalyptus tree (Kaewkla \& Franco, 2010).

Strain EUM $374^{\mathrm{T}}$ was isolated from a root of a eucalyptus tree, Eucalyptus microcarpa, during the course of research into molecular and culture-based methods of identifying endophytic actinobacteria (Coombs \& Franco, 2003; Conn \& Franco, 2004). In this paper we describe the morphological, physiological, chemotaxonomic and phylogenetic characteristics of this organism and propose that, based on the phenotypic and genotypic data, strain EUM $347^{\mathrm{T}}$ represents a novel species of the genus Pseudonocardia.

Samples of leaves, stems and roots were collected from a eucalyptus tree growing on the grounds of the Flinders University campus, Adelaide, South Australia, and processed within $4 \mathrm{~h}$ of collection. After removing the bark from the roots, the plant samples were sterilized with $70 \%$ ethanol and $6 \%$ hypochlorite for 5 min each followed by 
$10 \% \mathrm{NaHCO}_{3}$ for $10 \mathrm{~min}$. Crushed plant tissues were plated onto humic acid-vitamin B (HV) medium (Hayakawa \& Nonomura, 1987), solidified with $0.8 \%$ gellan gum instead of agar. The medium was adjusted to pH 7.2 and supplemented with $20 \mu \mathrm{g}$ nalidixic acid $\mathrm{ml}^{-1}$ and $100 \mathrm{U}$ nystatin $\mathrm{ml}^{-1}$ to repress the growth of bacteria and fungi, respectively. Plates were incubated at $27{ }^{\circ} \mathrm{C}$ for up to 12 weeks in sealed plastic boxes containing wet paper towels to maintain moisture. After incubation for 9 weeks, a Pseudonocardia-like strain, EUM $374^{\mathrm{T}}$, emerged on the HV-gellan gum plate. This strain was isolated, purified and maintained on half-strength potato dextrose agar (HPDA).

Genomic DNA from strain EUM $374^{\mathrm{T}}$ was extracted and the 16S rRNA gene was amplified and sequenced as described previously (Coombs \& Franco, 2003). The DNA $\mathrm{G}+\mathrm{C}$ content was determined by HPLC (Mesbah et al., 1989). The nearly complete $16 \mathrm{~S}$ rRNA gene sequence was corrected manually and aligned with sequences of closely related species obtained from the GenBank database by using BLAST (Altschul et al., 1997). The results were analysed by using the CLUSTAL_X program (Thompson et al., 1997) with Streptomyces griseus NRRL-ISP $5236^{\mathrm{T}}$ as the outgroup. Phylogenetic trees were reconstructed by using the neighbour-joining (Saitou \& Nei, 1987) and maximumparsimony (Kluge \& Farris, 1969) methods in MEGA version 4 (Tamura et al., 2007) software. Pairwise distances for the neighbour-joining algorithm were calculated according to the Kimura two-parameter model (Kimura, 1980) and close-neighbour interchange (search level=2, random addition=100) was applied in the maximum-parsimony analysis. The topology of the tree was evaluated by performing a bootstrap analysis (Felsenstein, 1985) based on 1000 replications.

The nearly complete 16S rRNA gene sequence of strain EUM $374^{\mathrm{T}}$ (1409 bp) was compared with 32 available sequences of species of the genus Pseudonocardia, showing sequence similarities of $93-96 \%$. Strain EUM $374^{\mathrm{T}}$ showed the highest 16S rRNA gene sequence similarities to $P$. spinosispora LM $141^{\mathrm{T}}(96.3 \%)$ and P. acaciae GMKU095 ${ }^{\mathrm{T}}$ (96.1\%). Phylogenetic analysis determined that strain EUM $374^{\mathrm{T}}$ belonged to the genus Pseudonocardia, grouping this strain with other members of the genus. The nearest phylogenetic neighbour was $P$. acaciae GMKU095 ${ }^{\mathrm{T}}$, which formed a distinct clade with strain EUM $347^{\mathrm{T}}$, supported by a bootstrap value of $92 \%$. The next closest phylogenetic neighbour was $P$. spinosispora LM $141^{\mathrm{T}}$ with bootstrap support of $84 \%$ (Fig. 1 and Supplementary Fig. S1, available in IJSEM Online). A phylogenetic tree reconstructed using all 32 available sequences of species of the genus Pseudonocardia is given in Supplementary Fig. S2. DNA-DNA relatedness studies were not carried out between strain EUM $374^{\mathrm{T}}$ and its closest phylogenetic relatives as the level of $16 \mathrm{~S}$ rRNA gene sequence similarity between them was less than $97 \%$, the cut-off point recommended for the delineation of bacterial species (Stackebrandt \& Goebel, 1994).
The genomic DNA G + C content of strain EUM $374^{\mathrm{T}}$ was $72.9 \mathrm{~mol} \%$, which is within the range of values typical of members of the genus Pseudonocardia (Huang et al., 2002).

Strain EUM $374^{\mathrm{T}}$ was subjected to a range of chemotaxonomic analyses. In order to quantify whole-cell fatty acid composition, cells were grown under static conditions for 14 days at $25{ }^{\circ} \mathrm{C}$ in TSB and harvested by centrifugation. Wet cells $(100 \mathrm{mg})$ were saponified, methylated and extracted according to Sasser (2001) and the resultant fatty acid methyl esters (FAME) were determined by following the protocols in the MIDI system (MIDI, 1993). Isoprenoid quinones were extracted and purified using the method of Collins et al. (1977) and analyzed by reversedphase LC-MS employing UV detection and electrospray MS. The solvent system was 2-propanol: methanol $(1: 1)$ at a flow rate of $1 \mathrm{ml} \mathrm{min}{ }^{-1}$. Whole cell hydrolysates were analysed for diaminopimelic acid isomers (Bousfield et al., 1985) and for sugars (Hasegawa et al., 1983). Mycolic acids were determined according to Minnikin et al. $(1975,1980)$ and acyl cell-wall analysis was performed according to Uchida et al. (1999).

The results showed that the diaminopimelic acid in wholecell hydrolysates of strain EUM $374^{\mathrm{T}}$ was in the mesoconfiguration and the whole-cell sugars were arabinose and galactose. These characteristics suggested that strain EUM $374^{\mathrm{T}}$ had a type IV cell wall and belonged to the family Pseudonocardiaceae. The cell wall was of the acetyl type and did not contain mycolic acids. Strain EUM $374^{\mathrm{T}}$ contained MK- $8\left(\mathrm{H}_{4}\right)$ as the predominant menaquinone. The wholecell fatty acid profile of EUM $374^{\mathrm{T}}$ was of the iso/anteiso branched type and consisted of iso- $\mathrm{C}_{15: 0}(26.68 \%)$, iso$\mathrm{C}_{16: 0} \quad(21.93 \%), \mathrm{C}_{16: 0} \quad(10.54 \%), \mathrm{C}_{17: 1} \omega 8 c \quad(10.38 \%)$, $\mathrm{C}_{16: 1} \omega 7 c(7.76 \%), \mathrm{C}_{17: 0} \quad(6.59 \%)$, iso- $\mathrm{C}_{17: 0}(4.04 \%)$, $\mathrm{C}_{16: 0}$ 10-methyl $(1.45 \%)$, iso- $\mathrm{C}_{14: 0}(1.31 \%)$ and anteiso$\mathrm{C}_{17: 0}(1.05 \%)$.

Morphological characteristics of strain EUM $374^{\mathrm{T}}$ were observed on eight different media: ISP 2, ISP 3, ISP 4, ISP 5, ISP 7, Bennett's agar, HPDA and nutrient agar (NA) (Atlas, 1993). To determine cell and spore morphology, cultures grown on ISP 2 for 14 days were mounted on a carbon adhesive tab without using a fixing agent, gold coated and viewed by scanning electron microscopy (SEM; ETEC Autoscan).

Cells of strain EUM $374^{\mathrm{T}}$ had a morphology typical of members of the genus Pseudonocardia and possessed aerial mycelia which fragmented into zig-zag-shaped spore chains. The rod-shaped spores had a knobby surface (Supplementary Fig. S3), which is unique in members of this genus. Colony morphologies of strain EUM $374^{\mathrm{T}}$ grown on different media are given in Table 1. On the media used, substrate mycelia were not present. The colour of aerial mycelium varied from white to brownish orange and spore colour varied from white through greyish yellow and orange to greenish grey. The strain did not produce any diffusible pigment. Growth occurred in liquid media under static conditions but not under shaking conditions. 


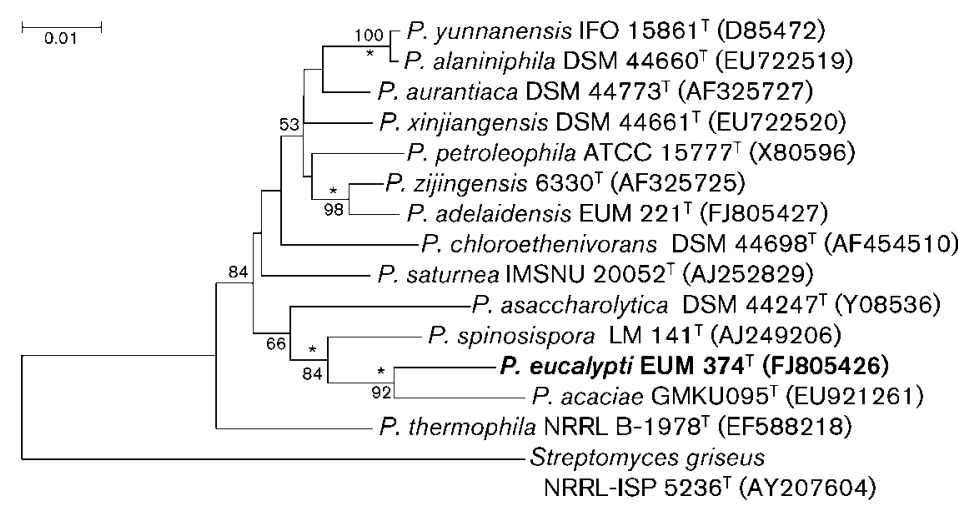

Fig. 1. Neighbour-joining tree showing the relationship between strain EUM $374^{\top}$ and related species of the genus Pseudonocardia using S. griseus as the outgroup. Asterisks indicate branches of the tree that were also recovered by using the maximum-parsimony algorithm (Supplementary Fig. S1). Bootstrap percentages based on 1000 resamplings are given at nodes. Bar, 0.01 substitutions per nucleotide position.
Strain EUM $374^{\mathrm{T}}$ had similar growth characteristics to its second closest phylogenetic neighbour, P. spinosispora LM $141^{\mathrm{T}}$; both were unable to grow under submerged conditions and did not produce substrate mycelia. On the other hand, the morphological features of these strains were different. Strain EUM $374^{\mathrm{T}}$ produced a zig-zag spore chain but $P$. spinosispora LM $141^{\mathrm{T}}$ did not produce spore chains with this morphology. Strain EUM $374^{\mathrm{T}}$ was also different from its closest neighbour, P. acaciae GMKU095 $5^{\mathrm{T}}$, as this type strain could grow under both static and shaking conditions and formed substrate mycelia on ISP 2 medium. Moreover, spores of both P. spinosispora LM $141^{\mathrm{T}}$ and $P$. acaciae GMKU095 ${ }^{\mathrm{T}}$ had spiny surfaces, whereas strain EUM $374^{\mathrm{T}}$ displayed spores with a knobby surface (Supplementary Fig. S3). It should be noted that, to date, among the genus Pseudonocardia, only these three species have been reported as having spores with protrusions on their surfaces.

Physiological and biochemical characterization was carried out as described by Gordon et al. (1974) and Kurup \& Schmitt (1973). The physiological characteristics that differentiate strain EUM $374^{\mathrm{T}}$ from the type strains of the two most closely related species of the genus Pseudonocardia (Lee et al., 2002; Duangmal et al., 2009) are displayed in Table 2. The three strains had different profiles of acid production from galactose, myo-inositol, mannitol and sorbitol (Table 2), differed in their ability to produce hydrogen sulfide, decompose tyrosine and hydrolyse gelatin and grew at different temperature ranges. Strain EUM $374^{\mathrm{T}}$ grew at $15-37{ }^{\circ} \mathrm{C}$, whereas P. spinosispora LM $141^{\mathrm{T}}$ and $P$. acaciae GMKU095 $5^{\mathrm{T}}$ grew at $4-30$ and $18-$ $42{ }^{\circ} \mathrm{C}$, respectively. Strain EUM $374^{\mathrm{T}}$ and $P$. acaciae

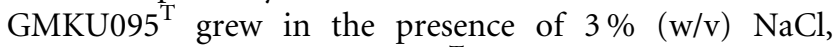
whereas $P$. spinosispora LM $141^{\mathrm{T}}$ did not grow under these conditions. Furthermore, strain EUM $374^{\mathrm{T}}$ could grow at pH 5-10, whereas $P$. acaciae GMKU $095^{\mathrm{T}}$ could only grow at $\mathrm{pH} 5-8$.

Based on phenotypic and genotypic evidence, strain EUM $374^{\mathrm{T}}$ represents a novel species of the genus Pseudonocardia, for which the name Pseudonocardia eucalypti sp. nov. is proposed.

\section{Description of Pseudonocardia eucalypti sp. nov.}

Pseudonocardia eucalypti (eu.ca.lyp'ti. N.L. gen. n. eucalypti of Eucalyptus, isolated from Eucalyptus microcarpa).

Cells are aerobic, Gram-reaction-positive, non-acid/alcoholfast and catalase- and urease-positive. Grows at $15-37{ }^{\circ} \mathrm{C}$

Table 1. Culture characteristics of strain EUM $374^{\top}$

ISP, International Streptomyces project. No soluble pigments or substrate mycelia were observed on any of the media tested.

\begin{tabular}{|lll|}
\hline Medium & Growth & Aerial mycelium \\
\hline Yeast extract malt extract agar (ISP 2) & Good & Pale, grey spore \\
Oatmeal agar (ISP 3) & Moderate & White, fine spore \\
Inorganic salt starch agar (ISP 4) & Poor & Pale, yellow spore \\
Glycerol asparagine agar (ISP 5) & Moderate & Greyish, orange spore \\
Tyrosine agar (ISP 7) & Moderate & Greying, yellow spore \\
Bennett's agar & Good & Greenish, grey spore \\
HPDA & Good & Yellowish, white spore \\
Nutrient agar & Moderate & Yellowish, white spore \\
\hline
\end{tabular}

${ }^{\star}$ Colour determination based on Methuen Handbook of Colour (Kornerup \& Wanscher, 1978). 
Table 2. Characteristics that differentiate strain EUM $374^{\top}$ from closely related type strains of species of the genus Pseudonocardia

Strains: 1, EUM $374^{\mathrm{T}}$ (data from this study); 2, $P$. acaciae GMKU095 $^{\mathrm{T}}$ (data from Duangmal et al., 2009); 3, P. spinosispora LM $141^{\mathrm{T}}$ (data from Lee et al., 2002). K, Knobby; s, spiny; +, positive; $\mathrm{W}$, weakly positive; - , negative; NR, not reported. All strains could produce acid from L-arabinose, D-fructose D-glucose, Dmannose, L-rhamnose, D-xylose and adonitol but not from maltose, melezitose or sucrose. All strains were positive for catalase. Urease production was positive for all strains but they could not hydrolyse casein.

\begin{tabular}{|lccc|}
\hline Characteristic & $\mathbf{1}$ & $\mathbf{2}$ & $\mathbf{3}$ \\
\hline Spore surface & $\mathrm{K}$ & $\mathrm{S}$ & $\mathrm{S}$ \\
Acid production from: & & & \\
$\quad$ D-Galactose & + & - & - \\
myo-Inositol & + & $\mathrm{W}$ & + \\
D-Mannitol & + & $\mathrm{W}$ & - \\
D-Sorbitol & $\mathrm{W}$ & - & - \\
Enzyme activity: & & & \\
$\mathrm{H}_{2}$ S production & - & - & + \\
Decomposition of tyrosine & + & + & - \\
Hydrolysis of: & & & \\
Gelatin & - & + & - \\
Starch & + & + & - \\
Growth at/in: & & & \\
Temperature range $\left({ }^{\circ} \mathrm{C}\right)$ & $15-37$ & $18-42$ & $4-30$ \\
pH range & $5-10$ & $5-8$ & $\mathrm{NR}$ \\
$37^{\circ} \mathrm{C}$ & $\mathrm{W}$ & + & - \\
$3 \% \mathrm{NaCl}$ & + & + & - \\
& & & \\
\hline
\end{tabular}

and $\mathrm{pH} 5-10$ (weakly at $37^{\circ} \mathrm{C}$ and $\mathrm{pH}$ 5). Does not produce hydrogen sulfide. Does not produce diffusible pigment. Aerial mycelia are white on ISP 3 but produce yellowishgreyish spores on other media and fragment to zig-zagshaped spore chains with rod-shaped spores that have knobby spore surfaces. Does not produce substrate mycelia. Grows on the surface of liquid media under static conditions but not under shaking conditions. Acid is produced from Larabinose, D-fructose, D-galactose, D-glucose, D-mannose, Lrhamnose, trehalose, D-xylose, adonitol, i-erythritol, myoinositol and D-mannitol, weakly from D-sorbitol but not from cellobiose, maltose, melezitose, methyl $\alpha$-D-glucoside or sucrose. Tyrosine and urea are degraded. Starch is hydrolysed but casein and gelatin are not. The cell wall contains meso-diaminopimelic acid. Whole-cell hydrolysate contains galactose and arabinose. The major menaquinone is MK-8( $\left.\mathrm{H}_{4}\right)$. Predominant whole-cell fatty acids are iso$\mathrm{C}_{15: 0}$ and iso- $\mathrm{C}_{16: 0}$.

The type strain, EUM $374^{\mathrm{T}}\left(=\mathrm{DSM} 45351^{\mathrm{T}}=\mathrm{ACM}\right.$ $\left.5285^{\mathrm{T}}\right)$, is an endophytic actinobacterium isolated from the root of a eucalyptus tree, Eucalyptus microcarpa, which was collected from the grounds of the Flinders University campus, Adelaide, South Australia. The DNA G+C content of the type strain is $72.9 \mathrm{~mol} \%$.

\section{Acknowledgements}

The authors thank for Greg Kirby for his assistance with the sampling of native plants, Daniel Jardine for menaquinone analysis and Kerry Gascoigne for SEM visualization. We are also grateful to Max Aravena-Roman for performing the MIDI-FAME analysis.

\section{References}

Altschul, S. F., Madden, T. L., Schäffer, A. A., Zhang, J., Zhang, Z., Miller, W. \& Lipman, D. J. (1997). Gapped BLAST and PSI-BLAST: a new generation of protein database search programs. Nucleic Acids Res 25, 3389-3402.

Atlas, R. M. (1993). Handbook of Microbiological Media. Edited by L. C. Parks. Boca Raton: CRC Press.

Bousfield, I. J., Keddie, R. M., Dando, T. R. \& Shaw, S. (1985). Simple rapid methods of cell wall analysis as an aid in the identification of aerobic coryneform bacteria. Soc Appl Bacteriol Tech Ser 20, 221236.

Chen, H. H., Qin, S., Li, J., Zhang, Y. Q., Xu, L. H., Jiang, C. L., Kim, C. J. \& Li, W. J. (2009). Pseudonocardia endophytica sp. nov., isolated from the pharmaceutical plant Lobelia clavata. Int J Syst Evol Microbiol 59, 559-563.

Collins, M. D., Pirouz, T., Goodfellow, M. \& Minnikin, D. E. (1977). Distribution of menaquinones in actinomycetes and corynebacteria. J Gen Microbiol 100, 221-230.

Conn, V. M. \& Franco, C. M. M. (2004). Analysis of the endophytic actinobacterial population in the roots of wheat (Triticum aestivum L.) by terminal restriction fragment length polymorphism and sequencing of 16S rRNA clones. Appl Environ Microbiol 70, 1787-1794.

Coombs, J. T. \& Franco, C. M. M. (2003). Isolation and identification of actinobacteria from surface-sterilized wheat roots. Appl Environ Microbiol 69, 5603-5608.

Duangmal, K., Thamchaipenet, A., Matsumoto, A. \& Takahashi, Y. (2009). Pseudonocardia acaciae sp. nov., isolated from roots of Acacia auriculiformis A. Cunn. ex Benth. Int J Syst Evol Microbiol 59, 14871491.

Evtushenko, L. I., Akimov, V. N., Dobritsa, S. V. \& Taptykova, S. D. (1989). A new species of actinomycete, Amycolata alni. Int J Syst Bacteriol 39, 72-77.

Felsenstein, J. (1985). Confidence limits on phylogenies: an approach using the bootstrap. Evolution 39, 783-791.

Gordon, R. E., Barnett, D. A., Handerhan, J. E. \& Pang, C. H. (1974). Nocardia coeliaca, Nocardia autotrophica, and the nocardin strain. Int J Syst Bacteriol 24, 54-63.

Gu, Q., Luo, H., Zheng, W., Liu, Z. \& Huang, Y. (2006). Pseudonocardia oroxyli sp. nov., a novel actinomycete isolated from surface-sterilized Oroxylum indicum root. Int J Syst Evol Microbiol 56, 2193-2197.

Hasegawa, T., Takisawa, M. \& Tanida, S. (1983). A rapid analysis for chemical grouping of aerobic actinomycetes. J Gen Appl Microbiol 29, 319-322.

Hayakawa, M. T. \& Nonomura, H. (1987). Humic acid-vitamin agar, a new medium for the selective isolation of soil actinomycetes. J Ferment Technol 65, 501-509.

Henssen, A. (1957). [Morphology and system of thermophilic actinomycetes]. Arch Mikrobiol 26, 373-414 (in German).

Huang, Y., Wang, L., Lu, Z., Hong, L., Liu, Z., Tan, G. Y. A. \& Goodfellow, M. (2002). Proposal to combine the genera Actinobispora and Pseudonocardia in an emended genus Pseudonocardia, and description of Pseudonocardia zijingensis sp. nov. Int J Syst Evol Microbiol 52, 977-982. 
Kaewkla, O. \& Franco, C. M. M. (2010). Pseudonocardia adelaidensis sp. nov., an endophytic actinobacterium isolated from the surfacesterilized stem of a grey box tree (Eucalyptus microcarpa). Int J Syst Evol Microbiol 60, 2818-2822.

Kimura, M. (1980). A simple method for estimating evolutionary rates of base substitutions through comparative studies of nucleotide sequences. J Mol Evol 16, 111-120.

Kluge, A. G. \& Farris, F. S. (1969). Quantitative phyletics and the evolution of anurans. Syst Zool 18, 1-32.

Kornerup, J. \& Wanscher, H. (1978). Methuen Handbook of Colour, 3rd edn. Edited by D Pavey. Fakenham, Norfolk: Cox \& Wyman Ltd.

Kurup, P. V. \& Schmitt, J. A. (1973). Numerical taxonomy of Nocardia. Can J Microbiol 19, 1035-1048.

Lee, S. D., Kim, E. S. \& Hah, Y. C. (2000). Phylogenetic analysis of the genera Pseudonocardia and Actinobispora based on 16S ribosomal DNA sequences. FEMS Microbiol Lett 182, 125-129.

Lee, S. D., Kim, E. S., Min, K. L., Lee, W. Y., Kang, S. O. \& Hah, Y. C. (2001). Pseudonocardia kongjuensis sp. nov., isolated from a gold mine cave. Int J Syst Evol Microbiol 51, 1505-1510.

Lee, S. D., Kim, E. S., Kang, S. O. \& Hah, Y. C. (2002). Pseudonocardia spinosispora sp. nov., isolated from Korean soil. Int $J$ Syst Evol Microbiol 52, 1603-1608.

Liu, Z. P., Wu, J. F., Liu, Z. H. \& Liu, S. J. (2006). Pseudonocardia ammonioxydans sp. nov., isolated from coastal sediment. Int J Syst Evol Microbiol 56, 555-558.

Mahendra, S. \& Alvarez-Cohen, L. (2005). Pseudonocardia dioxanivorans sp. nov., a novel actinomycete that grows on 1,4-dioxane. Int $J$ Syst Evol Microbiol 55, 593-598.

McVeigh, H. P., Munro, J. \& Embley, T. M. (1994). The phylogenetic position of Pseudoamycolata halophobica (Akimov et al. 1989) and a proposal to reclassify it as Pseudonocardia halophobica. Int J Syst Bacteriol 44, 300-302.

Mesbah, M., Premachandran, U. \& Whitman, W. B. (1989). Precise measurement of the $\mathrm{G}+\mathrm{C}$ content of deoxyribonucleic acid by high performance liquid chromatography. Int J Syst Bacteriol 39, 159-167.

MIDI (1993). Microbial Identification System Operational Manual. Newark, NJ: MIDI.
Minnikin, D. E., Alshamaony, L. \& Goodfellow, M. (1975). Differentiation of Mycobacterium, Nocardia, and related taxa by thin-layer chromatographic analysis of whole-organism methanolysates. J Gen Microbiol 88, 200-204.

Minnikin, D. E., Hutchinson, I. G., Caldicott, A. B. \& Goodfellow, M. (1980). Thin layer chromatography of methanolysates of mycolic acid containing bacteria. J Chromatogr A 188, 221-233.

Reichert, K., Lipski, A., Pradella, S., Stackebrandt, E. \& Altendorf, K. (1998). Pseudonocardia asaccharolytica sp. nov. and Pseudonocardia sulfidoxydans sp. nov., two new dimethyl disulfide-degrading actinomycetes and emended description of the genus Pseudonocardia. Int $J$ Syst Bacteriol 48, 441-449.

Saitou, N. \& Nei, M. (1987). The neighbor-joining method: a new method for reconstructing phylogenetic trees. Mol Biol Evol 4, 406425.

Sasser, M. (2001). Identification of bacteria by gas chromatography of cellular fatty acids, MIDI Technical note 101. Newark, DE: MIDI Inc.

Stackebrandt, E. \& Goebel, B. M. (1994). Taxonomic Note: a place for DNA-DNA reassociation and 16S rRNA sequence analysis in the present species definition in bacteriology. Int J Syst Bacteriol 44, 846849.

Tamura, K., Dudley, J., Nei, M. \& Kumar, S. (2007). MEGA 4: Molecular Evolutionary Genetics Analysis (MEGA) software version 4.0. Mol Biol Evol 24, 1596-1599.

Thompson, J. D., Gibson, T. J., Plewniak, F., Jeanmougin, F. \& Higgins, D. G. (1997). The CLUSTAL_X windows interface: flexible strategies for multiple sequence alignment aided by quality analysis tools. Nucleic Acids Res 25, 4876-4882.

Uchida, K., Kudo, T., Suzuki, K. I. \& Nakase, T. (1999). A new rapid method of glycolate test by diethyl ether extraction, which is applicable to a small amount of bacterial cells of less than one milligram. J Gen Appl Microbiol 45, 49-56.

Warwick, S., Bowen, T., McVeigh, H. \& Embley, T. M. (1994). A phylogenetic analysis of the family Pseudonocardiaceae and the genera Actinokineospora and Saccharothrix with 16S rRNA sequences and a proposal to combine the genera Amycolata and Pseudonocardia in an emended genus Pseudonocardia. Int J Syst Bacteriol 44, 293-299. 